\title{
Users' Perceptions on Internet Financial Reporting Practices in Emerging Markets: Evidence from Jordan
}

\author{
Khaldoon Al-Htaybat \\ Assistant Professor of Accounting \\ Accounting and Finance Department, Al-Hussein Bin Talal University \\ Ma'an, Jordan \\ E-mail: kaah@ahu.edu.jo \\ Larissa von Alberti-Alhtaybat (Corresponding author) \\ Assistant Professor of Accounting \\ International Accounting Department, School of Management and Logistic Sciences \\ German-Jordanian University, Amman, Jordan \\ E-mail: larissa.vonalberti@gju.edu.jo \\ Khaled Abed Hutaibat \\ Assistant Professor of Accounting \\ Accounting Department, Mu'tah University \\ P.O.Box 33, Karak, Jordan \\ E-mail: Hutaibat@mutah.edu.jo; Hutaibat@hotmail.com
}

Received: April 12, $2011 \quad$ Accepted: April 21, $2011 \quad$ doi:10.5539/ijbm.v6n9p170

\begin{abstract}
This study seeks to explore the perceptions of users regarding Internet financial reporting (IFR) practices in Jordan. A questionnaire survey of 200 possible participants of four different user-groups was conducted to investigate their perceptions regarding the usefulness and usability of IFR as a source of information in Jordan. 114 received responses were analysed using the Kruskal-Wallis test, and the analysis revealed that there is a strong agreement among the respondents on IFR being useable, accessible and available any time and from anywhere as a source of information for users' decision making in Jordan. However, users' perceptions regarding usefulness of IFR in decision making significantly differed. They addressed economic factors such as the cost of having Internet access and the cost of printing accounting information as two concerns regarding the future of IFR in Jordan. They also clarified that the traditional copy of the annual report is still the preferable source of accounting information for Jordanian users.
\end{abstract}

Keywords: Internet financial reports, Users’ perceptions, Emerging market, Jordan

\section{Introduction}

Financial reporting developed in the early twenty-first century from the traditional design of the printed annual report to the contemporary Internet Financial Reporting (IFR) aiming specifically to satisfy varying users' needs. Financial reporting is the common tool of disclosing companies' financial information, and it is predicted that IFR will gradually replace printed financial reporting as more companies will use IFR to provide financial information and communicate with accounting information users (Beattie and Pratt, 2003). In this context Oyelere et al (2003, p.38) argued that:

“Internet reporting improves users' access to information by providing information that meet their specific needs, allowing non-sequential access to information through the use of hyperlinks, interactive and research facilities, and allowing the opportunity for providing more information than available in the annual reports. This improved accessibility of information results in more equitable information dissemination among stakeholders". 
Although the literature addressing the concept of online reporting has been subject to increasing amounts of research over the last decade and is considered to be a user-oriented development, little is known about the users' perceptions regarding the role of online reporting in practices. Beattie and Pratt (2003) documented that none of the prior studies have asked the users of online reporting about their attitudes and preferences. In a similar vein, Quagli and Riva (2005) documented that very few prior studies deal with online reporting from the demand point of view.

One gap identified as part of the literature review is the theoretical background of prior studies, as argued by Xiao et al. $(2002,2004)$. This leaves the field of IFR research with a gap in theoretical guidance. The adopted theoretical background of the current study serves two purposes: filling the theoretical gap in IFR research and a meaningful context of the current study's findings. Pinsker (2007) has suggested the technology acceptance model (TAM), as an extension of theory of reasoned action (TRA), as a theoretical context for IFR research (Debreceny et al., 2007). The model has been applied extensively in the information systems context but provides most valuable insights into the perceived use and usability of IFR from a user's point of view (Debreceny, 2007). This study seeks to investigate the perceptions of users regarding IFR practices in Jordan from two angles: perceived usefulness and perceived usability, in line with Ghani et al (2009b). Usefulness will be used in this paper to express the users' views regarding the value of information provided by IFR for the decision making process. Usability focuses on the ease of access, clarity of IFR parts for users, and the ease of information search and ease of use of interface web applications. Therefore, a survey of four different user-groups, financial analysts, academics, bank credit officers and auditors, was undertaken to investigate their perceptions regarding the usefulness and usability of IFR as a source of information in Jordan.

Jordan was chosen in this study as one of the emerging markets in the Middle East confronted with new changes in the economic environment, the financial capital markets and the emergence of new interest in technological innovation and global network communication since the late-1990s. Internet use has grown rapidly in Jordan since then, as the Jordanian government initiated a new orientation towards using the Internet for different purposes, for instance using the Internet for providing news and comments online, with the result that Jordanians can obtain information from the Internet. Furthermore, individuals, corporations and organizations can establish their own Internet accounts easily without any government approval or registration required to open an account or set up a web site. In this context, the World Economic Forum published a competitiveness report of the telecommunications and information technology sector for the years 2009/2010. This study covered 133 countries, which were classified into four groups from high- to low-income based on gross national income (GNI) per capita, in order to compare the relationship of economic growth and technology. Jordan was ranked number 44 regarding readiness of taking advantage of technology the second year running. Furthermore, Jordan was ranked $7^{\text {th }}$ from the 16 Middle East and North Africa (MENA) region countries.

The Information Technology sector has developed greatly as can be understood from the World Bank findings. The achievements from 2005 until 2009 in the Information and Communication Technology sector are summarised in Table 1.

\section{Insert Table 1 about here}

The main aim of the next section of the paper is to outline the theoretical context and review key prior studies of IFR. Section 3 establishes the research design and discusses data collection. Section 4 presents the analysis of the data, and finally section 5 provides a discussion of the findings and the conclusion of the study.

\section{Prior studies}

The following section is divided into two parts: firstly the review of the theoretical context, technology acceptance model, and secondly the discussion of studies investigating users' perceptions.

\subsection{Theoretical background: technology acceptance model}

Technological developments have vastly changed the landscape of most fields and operations of research and business practices. Financial reporting has also been subject to such developments through the implementation of IFR and reporting languages, such as XBRL (Pinsker, 2007). Usefulness, usability and effectiveness are inevitable questions arising out of such new developments. To that end, Davis (1989) added an extension to the theory of reasoned action (Fishbein and Ajzen, 1975), which the author labeled Technology Acceptance Model (TAM) and which is illustrated in Figure 1. Theory of reasoned action suggests that individuals have the rational ability to use information, and that this processed information is used to achieve reasonable behaviors (Fishbein and Ajzen, 1975). TAM extends this and suggests that perceived usefulness and perceived ease of use of new information technology applications will influence the attitude towards and adoption of any application. TAM considers external variables as influential on perceived ease of use, which in turn influences perceived usefulness. Both of these aspects form potential users' attitudes towards the technological development, spurring behavioral intention of use and eventually actual use (Pinsker, 2007). In the context of IFR, this theoretical context suggests that external variables reflect a contingency approach (Xiao et al., 1996), as for instance a certain level of education and knowledge is necessary to be considered a representative user. Assuming the ability to make a rational assessment of IFR, the potential user then assesses how usable and useful IFR is, which explains their 
respective attitudes. From these findings, inferences can be made regarding the intention to use and the actual use of IFR.

\section{Insert Figure 1 about here}

\subsection{Prior research on users' perceptions}

The practices of IFR have been researched extensively focusing on the preparers' perceptions since the late 1990s: Several studies in the field were undertaken in various Western, Asian and Middle Eastern countries. These include in the US: Ashbaugh et al. (1999), and Ettredge et al. (2002). For Europe, following research studies were published: Craven and Marston (1999) in the UK; Gowthorpe and Amat (1999) in Spain; Pirchegger and Wagenhofer (1999) in Austria; Bonson and Escobar (2002) in 15 European countries; Marston and Polei (2004) in Germany; Andrikopoulos (2007) in Cyprus; Bozcuk et al (2008) in Turkey and Despina and Demetrios (2009) in Greece. Several studies were undertaken in Asia and Australasia, including Oyelere et al. (2003) in New Zealand; Marston (2003) in Japan, Lai et al. (2010) in Taiwan, Verma (2010) in India, Xiao et al. (2004) and Zhang et al (2007) in China. Finally, a number of studies were undertaken in Middle Eastern countries, for instance: Joshi and Al-Modhahki (2003) in Kuwait and Bahrain, Desoky (2009) and Aly et al. (2010) in Egypt, and Momany and Al-Shorman (2006), Al-Htaybat and Napier (2006), and Al-Hayale (2010) in Jordan.

All of these studies investigated IFR mainly from the viewpoint of what companies have to offer, i.e. the supply side. To that end, two research objectives were employed: a) investigate whether companies have websites and to which extent these companies offer financial information on these websites; b) investigate what is behind the differences in the level of IFR among the sampled companies, if any. Studies seeking to answer the first research objective were carried out mainly as descriptive surveys to provide empirical evidence on IFR practices by companies listed on a country's stock market. Some of these studies are for instance Lymer (1997); Lymer and Tallberg (1997); Deller et al., (1999); Hedlin (1999); Lymer et al. (1999); FASB (2000); and Lodhia et al, (2004), Al-Htaybat and Napier (2006), and Mohamed et al. (2009). Studies seeking to answer the second objective went one step further by measuring the level of the two basic dimensions, Presentation and Content, of IFR on companies' websites by using a disclosure checklist and examining company characteristics as explanatory factors of the differences between companies' IFR. Some of these include Craven and Marston (1999); Gowthorpe and Amat (1999); Ashbaugh et al. (1999); Pirchegger and Wagenhofer (1999); Ettredge et al.; (2002); Oyelere et al. (2003); Allam, and Lymer (2003); Marston and Polei (2004), and Almilia, (2009). Al-Hayale (2010) extended the range further by examining the advantages and obstacles of online reporting from the viewpoint of online investors and financial managers of the Jordanian manufacturing companies. He concludes that the cost of establishing and maintaining websites and the lack of regulations contribute to the infrequent use of online reporting by Jordanian manufacturing companies.

Furthermore, very few prior studies exploring the demand side examined IFR related issues. Such issues include the relationship between the level and the features of IFR and users' characteristics (Ettredge et al., 1999), users' information attitudes and preferences (Beattie and Pratt 2003), and users' preferences of the online reporting format and the effect of such format on decision-making (Ghani et al., 2009b). Furthermore, the effects of Hyperlinks, irrelevant and overload information on investor judgments (Dull et al. 2003, Kelton, 2007), and the implications of auditing of online financial information (Hodge, 2001; Khadaroo, 2005) were investigated. Jones and Xiao $(2003,2004)$ and Xiao et al. $(2002,2005)$ investigated the potential development and future trends as expected by expert users of IFR, with findings spanning a wide range (in total nine classifications) including expectations such as IFR being a mainstream source of information but traditional financial reporting still being actively used. Some studies are outlined in more detail in the remainder of this literature review, each of which specifically investigated users' points of view, perceptions or needs in relation to a specific aspect of IFR.

The first set of studies investigated users' perceptions of the actual information provided through IFR and whether such information had an impact upon their decision-making. Ettredge et al. (1999) analysed the online financial information provision of companies by comparing those that target sophisticated users with those that target less sophisticated users. They concluded that the sophisticated user generally led to a more extensive online data provision (for instance the full annual report), whereas the less sophisticated user was provided with more abbreviated financial information (for instance a summary of the annual report). The important factor of the study is that the assumption was that the users guided companies' online financial information provision.

Debrecency et al. (2001) determined three objectives for their study - identifying design attributes for IFR, ranking those attributes and undertaking a pilot test using the Web as a survey tool. Based on prior studies sixty-one attributes were identified, and the respondents suggested seven further objectives for completeness. In terms of ranking, the authors were surprised to find that participants ranked the traditional content of annual reports higher than forward-looking information, and similarly ranked traditional static attributes higher than dynamic ones. Generally, hyperlinks and other navigation aids were rated favourably, downloading files was ranked adversely. Regarding using the Web as a survey tool, the response rate was $13.2 \%$ which the authors identified as being lower than other similar projects (Debrecency et al., 2001). 
Hodge and Pronk (2006) examined whether professional and non-professional investors use varying online financial information, and whether there was a direct association between the information they were using and the investors' familiarity with the investment. The findings showed that professional users prefer to rely on the published financial statements in pdf format whereas non-professional users prefer the managers' take on the results in html format.

Gowthorpe (2004) researched the use of the Internet of smaller listed companies sharing corporate financial information with stakeholders. The author found that stakeholder requirements were assessed, albeit in a random manner, in order to amend inadequate corporate information provision. The effectiveness of IFR could not be determined in this context as the needs assessment was random and intuitive. However, it was concluded that the dialogue between companies and stakeholders had not yet been radically changed.

Khadaroo (2005) investigated whether the quality of IFR from a users' point of view had improved in light of the fast growth of IFR. The author suggests that one issue increasing the problem is the lack of auditing IFR, thus leaving auditors with little control over contents and changes made to audited information. The paper concludes suggesting that IFR should be standardized in order to protect users and improve credibility and reliability of financial information. Furthermore, corporate information provided on the Internet should be audited.

The second set of studies focuses more on the technology used for IFR and what users' perceptions of the varying reporting formats are. Hodge (2001) investigated whether firms can influence investors' perceptions of their financial reports by hyperlinking audited financial statements to unaudited information. The study found that this affected investors' judgement, and further misclassification of audited or un-audited financial information may mislead investors.

Hodge and Maines (2004) investigated whether XBRL-enhanced search engines help nonprofessional financial statement users get and use related financial information for investment decision-making. They found that while many users do not access this technology, those that do are better at getting and using information. They conclude that these search-facilitating technologies support users by increasing transparency of financial statement information and managers' choices for reporting that information. However, in order to get more users to access these technologies, greater publicity would be needed.

Dull et al. (2003) examined the effect of different presentation formats (hyperlinked versus non-hyperlinked) on decision-makers' judgments in terms of decisions, predictions, and the amount of information accessed. The researchers also examined the amount of time participants took to make decisions, and found that the presentation format impacted the time used to make a decision regarding assessment of small firms but not large firms.

Ghani et al. (2009b) investigated public accounting practitioners' points of view of three digital reporting formats, namely PDF, HTML and XBRL, used for IFR. Following a prior study (Davis, 1989 as stated in Ghani et al., 2009b), they determined two aspects of users' perceptions, perceived usefulness, considered to be performance enhancing, and perceived ease of use, considered to be effort-reducing or effortless, and examined the link between these users' perceptions, their preferred reporting format and the accuracy of their decision for which IFR was used. They found that ease of use was perceived similarly for all three reporting formats, whereas perception of usefulness varied greatly which was positively linked with their decision accuracy for HTML and XBRL, but not for PDF.

Finally, Beattie and Pratt (2003) looked at the demand side of IFR from a different angle, as they approached the topic from a users' expectations' and demand perspective, rather than an analysis of the current status quo of IFR. Rather than investigating actual information provision, they researched into changing and newly developing practices. They looked at users' perceptions of desirable additional information to be provided online, how useful certain navigation aids would be, and the ability to easily move information if provided in different formats. Their findings identified that expansions of IFR were favourable, that specific navigation tools and formats were considered useful, and that various groups favoured different formats. Overall the study looked into the future provision of financial information and the future application of technological tools from a users' point of view.

Apart from these studies, no further study on users' perceptions regarding the usefulness and usability of online reporting practices is available. Furthermore, none of the prior studies so far, to the best of our knowledge, collected a wide range of users' views regarding the usefulness and the usability of IFR practices in emerging markets. On the basis of TAM, this paper aims to report evidence about users' perceptions of the usefulness and usability of IFR practice in Jordan as one of the emerging markets. This serves to enhance our understanding of whether users consider IFR in such business environment as a useful and useable source of information for decision making. 


\section{Research design}

\subsection{Research objectives}

The main objective of this study is to carry out an empirical investigation to report the perceptions of four different user-groups, financial analysts, academics, bank credit officers and auditors, about IFR practices in Jordan as a source of information for decision-making. This study follows Ghani et al (2009b) who divided the users' perceptions regarding online reporting format into two elements: perceived usefulness and perceived ease of use. This also reflects the elementary concepts of TAM (Pinsker, 2007), which forms the theoretical background of the current investigation. Users' views on the value of information provided by IFR for the decision-making process are evaluated through questions on usefulness. Usability addresses users' perceptions of ease of access, clarity of IFR parts for users, and the ease of information search and ease of use of interface web applications. In order to achieve the objective of this study, we will seek answers to the following main questions that indicate the users' opinions of the perceived usefulness and usability of IFR as a source of information for their decision making process.

Question One: How is the usefulness of IFR perceived by interested external user groups in Jordan?

Question Two: How is the usability of IFR perceived by interested external user groups in Jordan?

The following null hypotheses were developed and are stated in their null form to facilitate the analysis.

Hypothesis 1: The usefulness of IFR is not perceived differently by interested external user-groups in Jordan.

Hypothesis 2: The usability of IFR is not perceived differently by interested external user-groups in Jordan.

\subsection{Research instrument}

To investigate these issues of IFR and to provide answers to the above-mentioned research questions, a new questionnaire was designed in both Arabic and English. The current questionnaire contains twenty-seven questions divided into three sections: The first section contains five questions seeking general information about the respondent's background profile, including their gender, age, qualifications, work experience and how often they use the Internet. This is customary for questionnaire development (see for instance Longden et al., 2001), as such questions seek information indicating whether respondents' answers qualify for inclusion (Al-Razeen and Karbhari, 2007). Furthermore, these serve certain aspects of the analysis, such as determining the association between age and perceived usefulness, and frequency of Internet usage and perceived usefulness of IFR. This is in line with TAM's external variables that affect perceived usability and usefulness (Davis, 1989).

The other two sections contain twenty-two statements related to the respondent's perceptions regarding the level of usefulness and usability of IFR for users' decision making. The sections were informed by Debrency et al. (2001), Khadaroo (2005), Hodge and Pronk (2006), and Ghani et al. (2009 a, b). The review of these studies led to the identification of the individual statements listed in the two sections. When writing a questionnaire, relevance of addressed topics is important. This is ascertained through review of the prior literature (Al-Razeen and Karbhari, 2007). Simplicity of questions and good structure of the questionnaire are important factors to consider (Al-Ajmi, 2009). Finally, a pilot test of the questionnaire should be considered, which was undertaken for this study.

The respondents were asked to determine the degree of importance of each item using a five-point Likert-type scale, where (1) referred to strongly disagree, and (5) to strongly agree. The first draft of this questionnaire was piloted and then modified in light of valuable comments and feedback of ten academics that either researched the area of financial reporting to some extent or were aware of IFR practices. Furthermore, Ghani et al's (2009b) questionnaire, developed prior to this study in order to investigate IFR, was used to inform the development of this questionnaire.

\subsection{Sampling method}

This questionnaire was distributed to 200 potential participants of four different users-groups: 35 out of 137 Jordanian financial analysts, 60 out of 1124 academics comprising members of business schools from private and public universities in Jordan, 55 out of 217 bank credit officers from different banks branches located in Jordan and 50 out 175 auditors working in Jordan. The choice of such diverse user groups was to cover a larger part of the interested Jordanian users and to collect data needed to provide valuable insights into IFR as a source of information for their decision-making processes. The number of respondents in each user group was determined by the agreement of respondents to participate in this study after personal contacts with the assistance provided by student research assistants getting in touch with a random number of users from each group to have their E-mail contacts in order to send them the questionnaire.

\section{Analysis}

\subsection{Response Rates of Survey}

The survey was commenced in June 2010 and continued until the end of July 2010; the duration of the data collection period was six weeks. On the $15^{\text {th }}$ of June 2010 , questionnaires were distributed among and sent by E-mail to our participants. The first reminder together with the original copy of the questionnaire was sent two 
weeks after the initial request. In some cases a second reminder was sent two weeks later to those who did not respond to us. In other cases the original copy of the questionnaire was delivered on the $15^{\text {th }}$ of July and collected two weeks later by hand in order to maximise the response rate. Overall 114 were fully completed and usable returned which represents a response rate equal to $57 \%$ of the participants, considered favorably according to Al-Subaihi (2008). The survey response description is presented in Table 2.

\section{Insert Table 2 about here}

The non-response bias test was used in the current study by comparing the responses of early and late respondents. After carrying out the Mann-Whitney U test at the 5\% confidence level, no significant differences between the two groups were found. The Cronbach's alpha test was used to statistically measure the internal consistency and reliability of the questionnaire (Botosan, 1997, Huck and Cormier, 1996). Cronbach's alpha ranges between (0) to indicate no correlation between the parts of the questionnaire and (1) to indicate perfect correlation between these parts. Although the alpha test is not of significance, Botosan (1997) suggests that 0.70 is an acceptable level, and Huck and Cormier (1996) indicate that 0.80 or above is the preferable level. The alpha value for the all respondents was 0.91, and the four separate user-groups are 0.93, 0.87, 0.79 and 0.89 respectively, suggesting a relatively high level of internal consistency and reliability of the responses collected from each of the user groups.

Since the objective of this study is to explore the users' perceptions of IFR practices, the objective of the statistical techniques is to analyse their perceptions collectively. The descriptive statistics, such as frequencies and measures of central tendencies, were adopted for data analysis. As the data of the current study was not normally distributed, and since there are more than two independent groups and their perceptions were measured on five-point Likert-type scale, the Kruskal-Wallis one-way analysis of variance was used by ranks (Siegel and Castellan, 1988; Field, 2003; Al-Razeen and Karbhari, 2007). This test was chosen as being appropriate for testing whether or not the mean perceptions of the 114 respondents among the four user groups are significantly different at the 5\% confidence level. By using this test the four groups were analysed collectively, as each group has a different number of respondents and the mean comparison in pairs is not adequate (Siegel and Castellan, 1988; Field, 2003; Al-Razeen and Karbhari, 2007). The rejection of the null hypothesis indicates that there is a significant difference between one or more pairs of the groups considered in the test.

\subsection{Results and Discussion}

The analysis of the survey results is reported in three sections: Respondents' background, perceived usefulness of IFR and perceived usability of IFR.

Respondents' background: Based on TAM, the first part of the questionnaire contains five questions seeking information on the personal characteristics of respondents. This includes their gender, age, qualifications, work experience and how often they use the Internet. The results reveal that respondents were $92 \%$ male, and holders of bachelor or higher degree in accounting or in business related areas, which indicates sufficient education and knowledge in the field of IFR, thus an important external variable is satisfactorily fulfilled. Furthermore, the findings indicate a low percentage of females in the following professions in Jordan: financial analysts, academia of business school in Jordanian universities, bank credit officers and auditing. Respondents were on average 32 years old, most (83\%) had had more than 5 years work experience and $96 \%$ of the respondents were frequent users of the Internet. The latter also poses an important external variable to judge perceived usability and usefulness. In general, it can be concluded that the respondents are qualified to provide the information sought through answering the questionnaire.

Perceived usefulness of IFR: Referring to TAM, perceptions of usefulness and usability affect the intention to use IFR. Accordingly, in the second part of the questionnaire respondents were asked to indicate to what extent IFR is useful for their decision making. To that end, the respondents were given eleven statements and were asked to indicate their level of agreement with each statement. A summary of the participants' responses is presented in Table 3.

\section{Insert Table 3 about here}

From Table 3, it is evident that users' perceptions regarding usefulness of IFR in decision making differ significantly. Respondents attached an average usefulness mean ranging from 4.67 being the highest to 2.2 being the lowest regarding each of the given statements, revealing feeble agreement on the usefulness of IFR for decision-making processes between the four user groups. The results show that all the participants provide the highest mean score for statement number 9: "IFR is providing information readily available from anywhere for use" (4.67), followed by statements number 10: "Using IFR facilities any time enables me to be more efficient" (4.16), and number 1: "IFR enables accessing information for my decision task more quickly" ranked third (4.13). In general, Table 3 illustrates that our respondents show differences regarding the remaining statements and ranked the overall usefulness of IFR as source of information for decision-making tasks, statement number 11 , with the lowest average mean (2.23).

As shown in Table 3, Kruskal Wallis tests were conducted for each of the eleven different statements to test Hypothesis 1 . The results revealed that there is no statistically significant difference in users' perceptions 
regarding statements number 1,9 , and 10 . Therefore, it can be concluded that all user groups believed that IFR as a communication system enables users to access published information quickly, at any time and from anywhere. This is consistent with Xiao et al. (2002)'s argument that online reporting is more likely to affect the traditional communicative aspects of annual reporting, such as access, dissemination, presentation and making accounting information electronically portable and globally accessible. Furthermore, the results indicate that there is a statistically significant difference in users' perceptions regarding statement number 6 "I do not have to rely on other sources of information as I can rely on IFR for my decisions". This means that Jordanian users have some concerns regarding relying on IFR as the only source of information to enable them to make a more informed decision. This result is also consistent with the findings reported by Al-Htaybat and Napier (2006). It was found that Jordanian companies listed on the Amman Stock Exchange with accessible and active home pages on the Internet in 2004 had an average level of disclosure (0.42) of 28 items of their disclosure index, which they considered to be a minimum acceptable level of online reporting. Also, the user groups have a significant difference regarding the degree of usefulness of statements number $3,4,5$ and 11 . Thus, the null hypothesis 1 was rejected for most of the given statements regarding the usefulness of IFR in Jordan. This is not surprising as statements 3,4 , and 5 focus on the usefulness of the presentation format of IFR for users to collect more relevant information in order to make informed decisions, while Jordanian companies use mainly the static format for online reporting such as PDF and HTML, as reported by Al-Htaybat and Napier (2006), and Momany and Al-Shorman (2006).

Perceived usability of IFR: In line with TAM, the third part of the questionnaire required respondents to indicate to what extent IFR is a usable source of information for their decision-making. Following Debreceny et al. (2001), usability is tested through three perspectives: the overall accessibility, the design and functionality, and navigation tools adopted for IFR. Issues of overall IFR accessibility refers to the design of making IFR usable and accessible to normal users, functionality of IFR means allowing for users to handle a wider range of information they require and need, efficiently, i.e. speed of access, downloading, and reading the information. Navigation tools refer to site maps, tables of contents, hyperlink, hypertext and indexes on each page of IFR. In order to determine this, the respondents were given eleven statements and were asked to indicate their level of agreement with each statement. A summary of the participants' responses is presented in Table 4.

\section{Insert Table 4 about here}

From the analyses of the given statements regarding usability of IFR in Jordan transpires that the users perceive each of the given statements with an average mean above 3.5. This reveals a strong agreement among the respondents on IFR being a useable, accessible and clear source of information for users' decision making in Jordan. The results show that all the participants provide the highest mean score for statement number 7: "The speed of access to any information in IFR is satisfactory" (4.67), followed by statement number 1: "IFR is easy to access and use for decision-making" (4.48), and statement number 2: "Links for information provided through IFR are very clear to use" (4.33). followed by statements number 5, 4, 3, 9 and 6 with average means of (4.15), (4.12), (3.81), (3.74) and (3.64) respectively. This result is not surprising as Jordanian companies are using easy, clear and basic electronic formats such as HTML and PDF for IFR. In general, Table 4 identifies that the respondents show some differences in their responses regarding statements number 8 "The cost of having Internet in order to access IFR facilities and printing any information is reasonable" with an average mean of (3.56), number 10 "the overall design of IFR in Jordan is at an acceptable level" (3.58), and number 11 "It is more preferable to read an Internet financial report than a hard copy report" with the lowest average mean (3.51).

Table 4 shows the results of the Kruskal Wallis tests conducted for each of the eleven different statements to test Hypothesis 2. The results show statements number 8,9 and 11 to be the three statements where users' perceptions differ significantly. Statement 8 raised the users' concern regarding the cost of having Internet in order to access IFR facilities. Access to the Internet in Jordan is, like in many other countries, not free, and the economic factors such as the cost of having Internet access and the cost of printing any information were a concern raised by our respondents. In the literature, cost is one the barriers to change printed reporting to online reporting (Xiao et al., 1996; Xiao et al., 2002). This concern was raised by the supply side, the preparers. Al-Hayale (2010) concludes that the cost of establishing and maintaining websites has contributed to the infrequent use of online reporting by Jordanian companies. This could be also applicable to the demand side as not all users have the financial abilities to afford having Internet access.

Furthermore, there was a significant difference among respondents' perceptions regarding the ease of distinguishing and identifying audited and non-audited information provided by IFR in Jordan. It is more common for Internet companies to provide a hyperlink from audited financial information to un-audited information (Xiao et al., 2002 and 2005). This is consistent with Hodge's (2001) conclusion that companies can influence users' perceptions by hyperlinking audited to unaudited information. Regarding the preference of reading an Internet financial report than reading a hard copy report, respondents preferred reading the traditional copy. This is consistent with the third view, reported by Xiao et al (2005), regarding the future survival of the traditional hard copy annual report, in which they state that even when the medium has changed from hardcopy to electronic media, the standardised annual report content will remain. In that context, Xiao et al. $(2002$, p. 250$)$ 
argue that the change in IFR is "conditional on cultural, economic, political, organizational and behavioural factors."

Finally, the results of the Kruskal Wallis tests show that there is no statistically significant difference among the respondents regarding the remaining statements. In general, the respondents agreed on IFR being a useable, accessible and clear source of information for users' decision making in Jordan, but they raised concerns regarding the current design of online reporting in Jordan. Thus, null hypothesis 2 was accepted for most of the given statements regarding the usability of IFR in Jordan. This is consistent with the results reported by Al-Htaybat and Napier (2006), as they found IFR in Jordan is located in the second generation of Internet usage because Jordanian companies are using the Internet as another communication channel to duplicate their printed financial statements using electronic formats (HTML and/or PDF) (see Hedlin 1999). Ghani et al. (2009b) also reported that $83 \%$ and $51 \%$ of the sixty-two respondents was familiar with PDF and HTML respectively, compared to $8 \%$ being familiar with XBRL. Among other reasons, they justified this result with users finding the former format easier and more reliable to use, clearer, more concise and understandable.

\section{Summary and conclusion}

The main purpose of this paper is to provide empirical evidence on the perceptions of users regarding IFR practices as a useful and useable source of information for decision-making in Jordan. The findings reflect on the theoretical context of TAM on several levels: firstly, external variables, such as education and relevant knowledge, play an important factor when identifying usefulness and usability of new technologies. This condition was satisfied by the selected user-groups. Furthermore, perceptions of usability and usefulness determine the intention to use a new information technology.

Four different Jordanian user groups were surveyed: financial analysts, academics, bank credit officers and auditors. The results reveal that there is a strong agreement among the respondents regarding IFR being a useable, accessible and clear source of information for users' decision making in Jordan. This is expected to have a positive effect on future intentions to use IFR and resulting actual use. It transpired that Jordanian users found online reporting accessible and available any time and from anywhere. This supports the original idea of the Internet's effect on the dissemination, and presentation of accounting information to make it electronically portable and globally accessible (Xiao et al. 2002). However, they were not confident in using IFR information and relying on it as the only source for decision making, as they considered there is only a minimum acceptable level of relevant up to date information and events provided online. This affects the perceived usefulness and impacts upon the intention to use and actual use of IFR. They also agreed that the IFR format and structure do not allow gathering more sufficient information for more informed decision-making, as the static formats for online reporting, such as PDF and HTML, are mainly used, as reported by Al-Htaybat and Napier, (2006) and Momany and Al-Shorman (2006). However, this study only focuses on the Jordanian context, and although providing a pioneer survey findings and inferences are limited to this. In order to get a fuller picture, future research should focus on a cross-country comparison of users' perceptions of IFR. Current findings can be generalised in the context of similar emerging market settings. Furthermore, it would be most useful for future research to extend the investigation of the relationship of IFR and TAM, and investigate whether perceived usability and usefulness in fact influence actual use of IFR.

In general, users' perceptions regarding the usefulness of IFR in decision making differ significantly, and economic factors such as the cost of having Internet access and the cost of printing accounting information were raised as a concern regarding the future of IFR in Jordan. This indicates that an external variable, such as cost of Internet access, can influence the perceived usefulness of IFR. One possible remedy to the cost of Internet access could be to open the market for new telecommunication providers, thus introduce competitive pricing, as currently the market is rather monopolistic. The users also clarified that the traditional copy of the annual report is the preferable source for Jordanian users to read, in line with Xiao et al. (2002)'s finding that users might be reluctant to adapt to technological change. This can be attributed to the users' culture but also a lack of Internet familiarity, which can be solved by increased education at schools and universities, and governmentally run centers for youth education with free classes on computing and Internet skills. A further factor to consider is that new generations will use the Internet, thus IFR, more readily and comfortably. Ultimately, as Xiao et al. (2002) argue, the change in IFR is "conditional on cultural, economic, political, organizational and behavioral factors" (Xiao et al., 2002, p. 250).

\section{References}

Al-Ajmi, J. (2009). Investors' use of corporate reports in Bahrain. Managerial Auditing Journal, Vol. 24, No. 3, pp. 266 - 289. doi:10.1108/02686900910941140, http://dx.doi.org/10.1108/02686900910941140

Al-Hayale, T. (2010). Financial reporting on the internet in the Middle East: the case of Jordanian industrial companies. International Journal of Accounting and Finance, Vol. 2, No. 2, pp. 171-191. doi:10.1504/IJAF.2010.032087, http://dx.doi.org/10.1504/IJAF.2010.032087

Al-Htaybat, K., and Napier, C. (2006). Online corporate financial reporting in developing countries: the case of Jordan', paper presented at the BAA Annual Conference, Portsmouth University, Portsmouth. 
Allam, A., and Lymer, A. (2003). Developments in Internet financial reporting: Review and Analysis across Five Developed Countries. International Journal of Digital Accounting Research, Vol. 3, No. 6, pp. 165 - 206.

Almilia, L. S. (2009). Determining Factors of Internet Financial Reporting In Indonesia. Accounting \& Taxation, $1(1), 87-99$.

Al-Razeen, A., and Karbhari, Y. (2007). An Empirical Investigation into The Importance, Use, And Technicality of Saudi Annual Corporate Information. Advances in International Accounting, Vol. 20, pp. 55 - 74. doi:10.1108/10569210480000183, http://dx.doi.org/10.1108/10569210480000183

Al-Subaihi, A. A. (2008). Comparison of Web and Telephone Survey Response Rates in Saudi Arabia. The Electronic Journal of Business Research Methods, Volume 6, No, 2, pp. 123 - 132

Aly, D., Jon, S., and Hussainey, K. (2010). Determinants of corporate internet reporting: evidence from Egypt. Managerial Auditing Journal, Vol. 25, No. 2, pp.182-202. doi:10.1108/02686901011008972, http://dx.doi.org/10.1108/02686901011008972

Andrikopoulos, A. (2007). Financial reporting practices on the internet: the case of companies listed in the Cyprus Stock Exchange. Working paper, University of the Aegean, Greece.

Ashbaugh, H., Johnstone, K.M., and Warfield, T.D. (1999). Corporate reporting on the Internet. Accounting Horizons, Vol. 13, No. 3, pp. 241-258.

Bonson, E., and Escobar, T. (2002). A survey on voluntary disclosure on the Internet: empirical evidence from 300 European Union companies. The International Journal of Digital Accounting Research, Vo. 2, No. 1, pp.27-51. doi:10.4192/1577-8517-v2_2, http://dx.doi.org/10.4192/1577-8517-v2_2

Botosan, C.A. (1997). Disclosure level and the cost of equity capital. The Accounting Review, Vol. 72, pp. 323-49.

Bozcuk, A., Arzova, S. B., \& Aslan, S. (2008). Internet financial reporting: the case of Turkey. Akdeniz University, Antalya, Turkey, available at: S, (Last accessed 1 August 2010)

Craven, B.M., and Marston, C.L. (1999). Financial reporting on the Internet by leading UK companies. European Accounting Review, Vol. 8, No. 2, pp. 321-333. doi:10.1080/096381899336069, http://dx.doi.org/10.1080/096381899336069

Davis, F. D. (1989). Perceived usefulness, perceived ease of use, and user acceptance of information technology. MIS Quarterly, Vol. 13, No.3, pp. 319-340

Debreceny, R. S., Gray, G. L., and Mock, T. J. (2001). Financial Reporting Web Sites: What Users Want in Terms of Form and Content. The International Journal of Digital Accounting Research, Vol. 1, No. 1, pp.1-24.

Debreceny, R.S. (2007). 'Research into XBRL - old and new challenges', in: Debreceny, R.S., Felden, C. and Piechocki, M. (eds) (2007), New dimensions of business reporting and XBRL, Wiesbaden: DUV

Debreceny, R.S., Felden, C., and Piechocki, M (eds). (2007). New dimensions of business reporting and XBRL, Wiesbaden: DUV

Deller, D., Stubenrath, M., and Weber, C. (1999). A survey on the use of the Internet for investor relations in the USA, UK and Germany. European Accounting Review, Vol. 8, No. 2, pp. 351-64. doi:10.1080/096381899336087, http://dx.doi.org/10.1080/096381899336087

Desoky, A. (2009). Company Characteristics as Determinants of Internet Financial Reporting In Emerging Markets: The Case of Egypt. Accounting in Emerging Economies: Research in Accounting in Emerging Economies, Vol. 9, pp. 31-71. doi:10.1108/S1479-3563(2009)0000009004, http://dx.doi.org/10.1108/S1479-3563(2009)0000009004

Despina. A., and Demetrios., P. (2009). The web-based financial reporting adopted by the listed companies in the Athens Stock Exchange. Journal of Modern Accounting and Auditing, Vol. 5, No. 7, pp. 7-20.

Dull, R. B., A. W. Graham and A. A. Baldwin. (2003). Web-Based Financial Statements: Hypertext Links to Footnotes and Their Effects on Decisions. International Journal of Accounting Information Systems, Vol. 4, pp. 185-203. doi:10.1016/S1467-0895(03)00009-5, http://dx.doi.org/10.1016/S1467-0895(03)00009-5

Ettredge, M. L., Richardson, V. J., and Scholz, S. (1999). Financial data at corporate web sites: does user sophistication matter?' doi:10.2139/ssrn.142936, http://dx.doi.org/10.2139/ssrn.142936

Ettredge, M., Richardson, V. J., and Scholz, S. (2002). Dissemination of information for investors at corporate web sites. Journal of Accounting and Public Policy, Vol. 21, pp. 357-369. doi:10.1016/S0278-4254(02)00066-2, http://dx.doi.org/10.1016/S0278-4254(02)00066-2

Field, A. (2003). Discovering Statistics Using SPSS for Windows; Advanced Techniques for the Beginner. London, SAGE Publications.

Financial Accounting Standards Board. (2000). Business reporting research project: electronic distribution of business information. Norwalk: FASB. 
Fishbein, M., and Ajzen, I. (1975). Belief, attitude, intention, and behavior: An introduction to theory and research. Reading, MA: Addison-Wesley.

Ghani, E. K., Laswad, F., and Tooley, S. (2009b). Digital Reporting Formats: Users' Perceptions, Preferences and Performances. The International Journal of Digital Accounting Research, Vol. 9, pp. 45-98.

Ghani, E. K., Laswad, F., Tooley, S., and Jusoff, K. (2009a). The Role of Presentation Format on Decision-makers' Behaviour in Accounting. Business Research, January, Vol. 2, No. 1, pp. 183-195.

Gowthorpe, C. (2004). Asymmetrical dialogue? Corporate financial reporting via the Internet', Corporate Communications: an International Journal, Vol. 9, No.4, pp. 283 -293. doi:10.1108/13563280410564020, http://dx.doi.org/10.1108/13563280410564020

Gowthorpe, C., and Amat, O. (1999). External reporting of accounting and financial information via the internet in Spain. The European Accounting Review, Vol. 8, No. 2, pp. 365-71. doi:10.1080/096381899336096, http://dx.doi.org/10.1080/096381899336096

Hedlin, P. (1999). The Internet as a vehicle for investor relations: the Swedish case. European Accounting Review, Vol. 8, No. 2, pp. 373-81. doi:10.1080/096381899336104, http://dx.doi.org/10.1080/096381899336104

Hodge, F. (2001). Hyperlinking un-audited information to audited financial statements: Effects on investor judgments. The Accounting Review, Vol. 76, No. 10, pp. 675-691

Hodge, F., and Pronk, M. (2006). The impact of expertise and investment familiarity on investors' use of online financial reporting information. Journal of Accounting, Auditing and Finance, Summer, pp. 267-292.

Hodge, F.D., Kennedy, J.J., and Maines, L.A. (2004). Does search facilitating technology improve the transparency of financial reporting?. Accounting Review, Vol. 79, No. 3, pp. 687-703. doi:10.2308/accr.2004.79.3.687, http://dx.doi.org/10.2308/accr.2004.79.3.687

Huck, S. W., and Cormier, W. H. (1996). Reading statistics and research. New York: Harper Collins College Publishers

Jones, M.J., and Xiao, J.Z. (2003). Internet reporting: current trends and trends by 2010. Accounting Forum, Vol. 27, No. 2, pp. 132-165.

Jones, M.J., and Xiao, J.Z. (2004). Financial reporting on the Internet by 2010: a consensus view. Accounting Forum, Vol. 28, pp. 237-263. doi:10.1016/j.accfor.2004.07.002, http://dx.doi.org/10.1016/j.accfor.2004.07.002

Jordan Business Report (2009), THE REPORT Jordan 2009, prepared by Oxford Business Group. [Online] Available: www.oxfordbusinessgroup.com (Last accessed 1 August 2010)

Joshi, P., and Al-Modhahki, J. (2003). Financial reporting on the internet: Empirical evidence from Bahrain and Kuwait. Asian Review of Accounting, Vol. 11, No. 1, pp. 88 - 101. doi:10.1108/eb060764, http://dx.doi.org/10.1108/eb060764

Kelton, A.S. (2007). 'Internet Financial Reporting: The Effects of Hyperlinks and Irrelevant Information on Investor Judgments', paper presented at American Accounting Association 2007 Information System Section Midyear Conference January 5- 6, 2007 and AIS New Scholars Consortium January 3- 4, 2007 Savannah, Georgia.

Khadaroo, I. (2005). Corporate reporting on the internet: some implications for the auditing profession', Managerial Auditing Journal, Vol. 20, No. 6, pp. 578-591. doi:10.1108/02686900510606074, http://dx.doi.org/10.1108/02686900510606074

Lai, S. C., Lin, C., Li, H. C., \& Wu, F. H. (2010). An Empirical Study of the Impact of Internet Financial Reporting on Stock Prices. International Journal of Digital Accounting Research, Vol. 10, pp. 1-26.

Lodhia, S. K., Allam, A., and Lymer, A. (2004). Corporate reporting on the Internet in Australia: an exploratory study. Australian Accounting Review, Vol. 14, No. 3, pp. 64-71. doi:10.1111/j.1835-2561.2004.tb00242.x, http://dx.doi.org/10.1111/j.1835-2561.2004.tb00242.x

Longden, S., Luther, R., and Bowler, D. (2001). Management Accounting in a Society Undergoing Structural Change: A Southern African Study, London, The Chartered Institute of Management Accountants.

Lymer, A. (1997). 'The use of the Internet in company reporting: a survey and commentary on the use of the WWW in corporate reporting in the UK', Paper presented at the 1997 BAA National Conference, 21-25 March 1997, Birmingham.

Lymer, A., and Tallberg, A. (1997). Corporate reporting and the Internet - a survey and commentary on the use of the WWW in corporate reporting in the UK and Finland', Paper presented at the 20th Annual Congress of the European Accounting Association, Antwerp, Belgium.

Lymer, A., Debreceny, R., Gray, G. L., and Rahman, A. (1999). Business reporting on the Internet. London: IASC.

Marston, C. (2003). Financial reporting on the Internet by leading Japanese companies. Corporate 
Communications, Vol. 8, No. 1, pp. 23-27. doi:10.1108/13563280310458894, http://dx.doi.org/10.1108/13563280310458894

Marston, C., and Polei, A. (2004). Corporate reporting on the Internet by German companies. International Journal of Accounting Information Systems, Vol. 5, pp. 285-311. doi:10.1016/j.accinf.2004.02.009, http://dx.doi.org/10.1016/j.accinf.2004.02.009

Mohamed, E., Oyelere, P., and Al-Busaidi, M. (2009). A survey of internet financial reporting in Oman. International Journal of Emerging Markets, Vol. 4, No. 1, pp. 56-71. doi:10.1108/17468800910931670, http://dx.doi.org/10.1108/17468800910931670

Momany, M., \& Al-Shorman S. (2006). Web-Based Voluntary Financial Reporting of Jordanian Companies. International Review of Business Research Papers, Vol. 2, No.3, pp. 127 - 139.

Oyelere, P., Laswad, F., and Fisher, R. (2003). Determinants of Internet financial reporting by New Zealand listed companies. Journal of International Financial Management and Accounting, Vol. 14, No. 1, pp. 26-63. doi:10.1111/1467-646X.00089, http://dx.doi.org/10.1111/1467-646X.00089

Pinsker, R. (2007). A theoretical framework for examining the corporate adoption decision involving XBRL as a continuous disclosure reporting technology', in: Debreceny, R.S., Felden, C. and Piechocki, M. (eds) (2007), New dimensions of business reporting and XBRL, Wiesbaden: DUV

Pirchegger, B., and Wagenhofer, A. (1999). Financial information on the Internet: a survey of the homepages of Austrian companies. European Accounting Review, Vol. 8, No. 2, pp. 383-395. doi:10.1080/096381899336113, http://dx.doi.org/10.1080/096381899336113

Quagli, A., and Riva, P. (2005). Do Financial Websites Meet the Users' Information Needs? A Survey From the Italian Context, Available at SSRN: http://ssrn.com/abstract=863744 (Last accessed 1 August 2010)

Sekaran, U. (1992). Research Methods for Business: A Skill-building Approach. Wiley: New York, NY.

Siegel, S., and Castellan, N. J. (1988). Nonparametric Statistics for the Behavioral Sciences, $2^{\text {nd }}$ edition. Singapore, McGraw-Hill Book Company, Inc.

Verma, D. (2010). Web-based Business Reporting in Indian Corporate Sector. Journal of Knowledge Management Practice, Vol. 11, Special Issue 1.

Xiao, J.Z., Dyson, J., and Powell, P. (1996). The impact of information technology on corporate financial reporting: a contingency perspective. British Accounting Review, Vol. 28, No. 3, pp. 203-27. doi:10.1006/bare.1996.0015, http://dx.doi.org/10.1006/bare.1996.0015

Xiao, J.Z., Jones, M.J., and Lymer, A. (2002). Immediate trends in Internet reporting. European Accounting Review, Vol. 11, No. 2, pp. 245-275. doi:10.1080/09638180020017087a, http://dx.doi.org/10.1080/09638180020017087a

Xiao, J.Z., Jones, M.J., and Lymer, A. (2005). A conceptual framework for investigating the impact of the internet on corporate financial reporting. The International Journal of Digital Accounting Research, Vol. 5, No. 10, pp. 131-169.

Xiao, J.Z., Yang, H., and Chow, C.W. (2004). The determinants and characteristics of voluntary Internet-based disclosures by listed Chinese companies. Journal of Accounting and Public Policy, Vol. 23, pp. 191-225. doi:10.1016/j.jaccpubpol.2004.04.002, http://dx.doi.org/10.1016/j.jaccpubpol.2004.04.002

Zhang, T., He, Y., and Gao, S.S. (2007). "The determinants of internet financial reporting: empirical evidence from China', paper presented at the BAA Annual Conference, Royal Holloway, University of London, London.

Table 1. The Achievement from 2005 until 2009 in the ICT Sector

\begin{tabular}{|l|c|c|c|c|c|}
\hline Number of Subscribers: (000) & $\mathbf{2 0 0 5}$ & $\mathbf{2 0 0 6}$ & $\mathbf{2 0 0 7}$ & $\mathbf{2 0 0 8}$ & $\mathbf{2 0 0 9}$ \\
\hline Fixed Phone & 628 & 614 & 559 & 519 & 501 \\
Mobile and Trunking & 3138 & 4343 & 4772 & 5,314 & 6,014 \\
Internet (Subscribers) & 197 & 206 & 228 & 229 & 244 \\
Internet (Users) & 720 & 770 & 1,163 & 1,500 & 1,742 \\
Volume of Investments in Internet (Million JD) & 5.6 & 2.3 & 11.1 & 22 & 31 \\
\hline
\end{tabular}

Source: Telecom Market Statistics, www.trc.gov.jo, Telecommunication Regulatory Commission 
Table 2. The Description of Survey Response Rates

\begin{tabular}{|l|c|c|c|}
\hline Group & \multicolumn{3}{|c|}{ Questionnaires } \\
& Total Distributed & Useable Returned & Response Rate (\%) \\
\hline Financial Analysts & 35 & 22 & 63 \\
Academics & 60 & 34 & 57 \\
Bank Credit Officers & 55 & 37 & 67 \\
Auditors & 50 & 21 & 42 \\
Total & 200 & 114 & 57 \\
\hline
\end{tabular}

Table 3. Users' Perception on the Usefulness of IFR

\begin{tabular}{|c|c|c|c|c|c|}
\hline \multicolumn{6}{|c|}{ Kruskal Wallis Test } \\
\hline Statements of Usefulness & $\begin{array}{l}\text { Average } \\
\text { mean }\end{array}$ & SD & Rank & $\mathbf{X}^{2}$ & Sign \\
\hline $\begin{array}{l}\text { 1. IFR enables accessing information for my decision making } \\
\text { task more quickly. }\end{array}$ & 4.13 & 1.13 & 3 & 2.65 & 0.632 \\
\hline $\begin{array}{l}\text { 2. IFR as a communication system enables me to make a more } \\
\text { informed decision. }\end{array}$ & 2.27 & 1.84 & 10 & 8.36 & 0.043 \\
\hline $\begin{array}{l}\text { 3. IFR format and structure allows me to gather more information } \\
\text { for my decision-making tasks. }\end{array}$ & 3.45 & 1.34 & 5 & 9.40 & 0.024 \\
\hline $\begin{array}{l}\text { 4. IFR contains relevant information for decision-making tasks } \\
\text { (up to date information and events) }\end{array}$ & 2.35 & 1.75 & 9 & 6.46 & 0.028 \\
\hline $\begin{array}{l}\text { 5. The IFR presentation format allows me to gather more } \\
\text { sufficient information for decision-making. }\end{array}$ & 3.81 & 1.25 & 4 & 7.45 & 0.031 \\
\hline $\begin{array}{l}\text { 6. I do not have to rely on other sources of information as I can } \\
\text { rely on IFR for my decisions }\end{array}$ & 2.44 & 1.96 & 6 & 0.065 & 0.044 \\
\hline 7. IFR contains adequate information for my decisions & 2.41 & 1.77 & 7 & 7.74 & 0.032 \\
\hline 8. I am confident in using IFR information for my decisions & 2.38 & 1.82 & 8 & 5.42 & 0.038 \\
\hline $\begin{array}{l}\text { 9. IFR is providing information readily available from } \\
\text { anywhere for use }\end{array}$ & 4.67 & 1.12 & 1 & 4.31 & 0.571 \\
\hline 10. Using IFR facilities any time enables me to be more efficient & 4.16 & 1.15 & 2 & 6.65 & 0.134 \\
\hline $\begin{array}{l}\text { 11. Overall IFR is a useful source of information for } \\
\text { decision-making tasks }\end{array}$ & 2.23 & 1.87 & 11 & 3.66 & 0.013 \\
\hline
\end{tabular}

Table 4. Users' Perception on the Usability of IFR

\begin{tabular}{|c|c|c|c|c|c|}
\hline & \multicolumn{5}{|c|}{ Kruskal Wallis Test } \\
\hline Statements of Usability & $\begin{array}{l}\text { Average } \\
\text { mean }\end{array}$ & SD & Rank & $\mathbf{X}^{2}$ & Sign \\
\hline s and use for decision-making. & 4.48 & 1.23 & 2 & 9.43 & 0.461 \\
\hline $\begin{array}{l}\text { 2. Links for information provided through IFR are very clear } \\
\text { to use. }\end{array}$ & 4.33 & 1.32 & 3 & 7.25 & 0.342 \\
\hline to hecome of & 3.81 & 1.67 & 6 & 4.37 & 0.175 \\
\hline 4.It & 4.1 & 1.19 & 5 & 5.18 & 0.263 \\
\hline $\begin{array}{l}\text { 5. The overall layout structure and format of IFR is very easy } \\
\text { to use. }\end{array}$ & 4.15 & 1.06 & 4 & 3.62 & 0.064 \\
\hline $\begin{array}{l}\text { 6. The navigation tools of IFR are available and easy to use } \\
\text { ( search engine, hypertext, map of content, indexes) }\end{array}$ & 3.64 & 1.22 & 7 & 5.42 & 0.243 \\
\hline $\begin{array}{l}\text { 7. The speed of access to any information in IFR is } \\
\text { satisfactory }\end{array}$ & 4.67 & 1.19 & 1 & 7.54 & 0.674 \\
\hline $\begin{array}{l}\text { 8. The cost of having Internet in order to access IFR } \\
\text { facilities and printing any information is reasonable }\end{array}$ & 3.56 & 1.21 & 10 & 8.65 & 0.023 \\
\hline $\begin{array}{l}\text { 9. It is easy to identify audited and non-audited information } \\
\text { provided by IFR }\end{array}$ & 3.74 & 1.13 & 8 & 6.52 & 0.012 \\
\hline 10. Overall design of IFR in Jordan is at an acceptable level. & 3.5 & 1.23 & 9 & 5.32 & 0.058 \\
\hline $\begin{array}{l}\text { 11. It is more preferable to read an Internet financial report } \\
\text { than a hard copy report }\end{array}$ & 3.51 & 1.75 & 11 & 9.25 & 0.034 \\
\hline
\end{tabular}




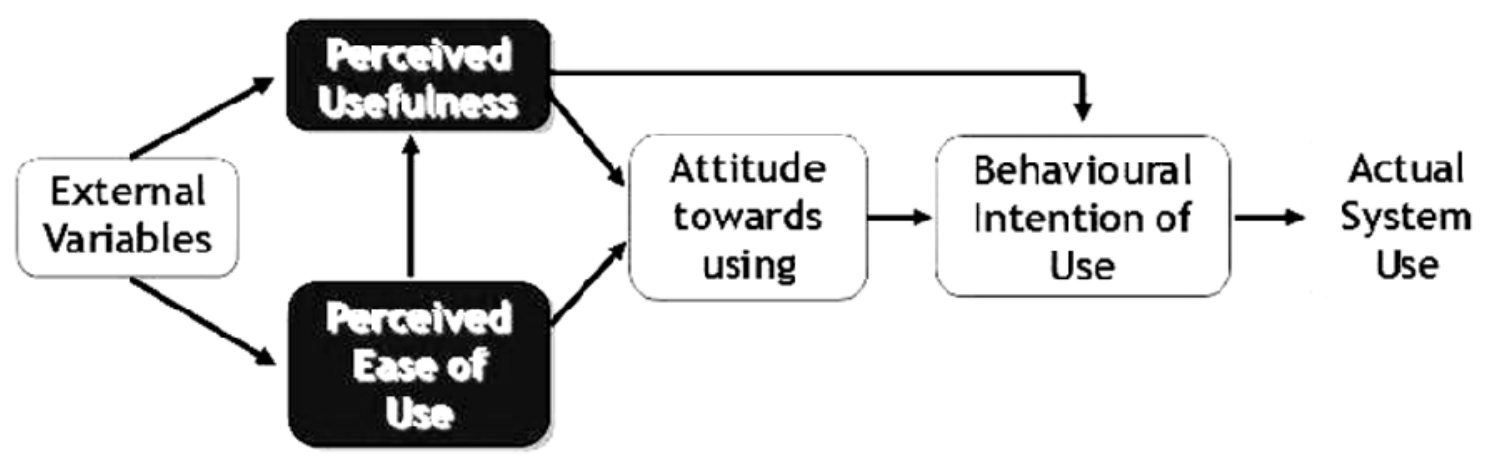

Adopted from Davis (1989)

Figure 1. The Technology Acceptance Model 